
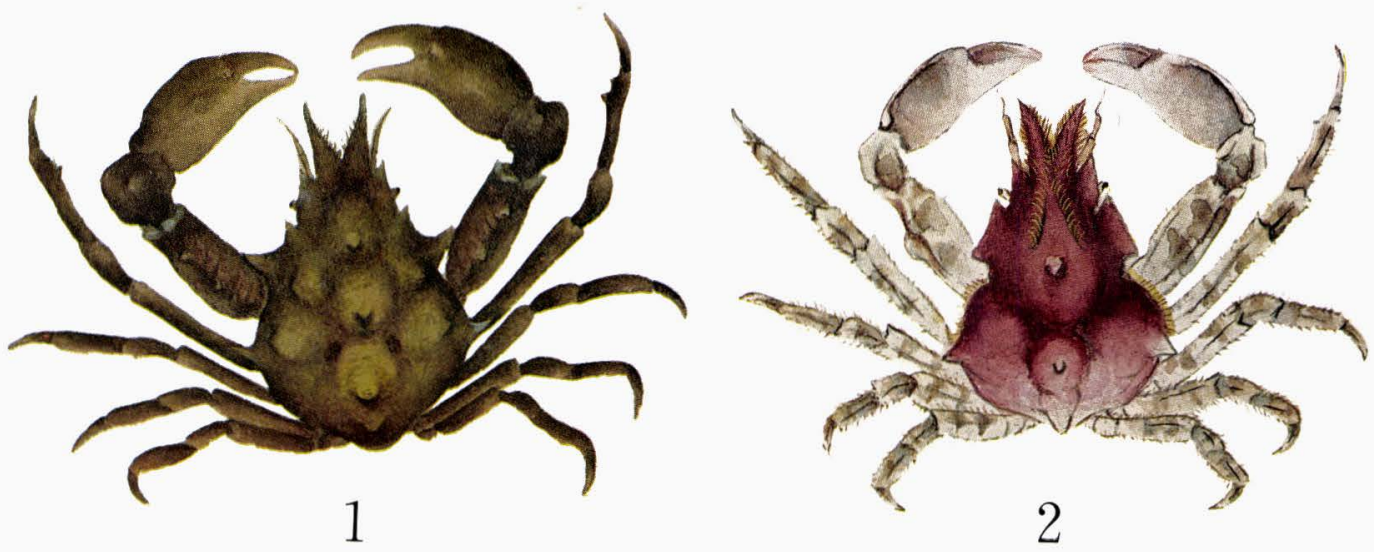

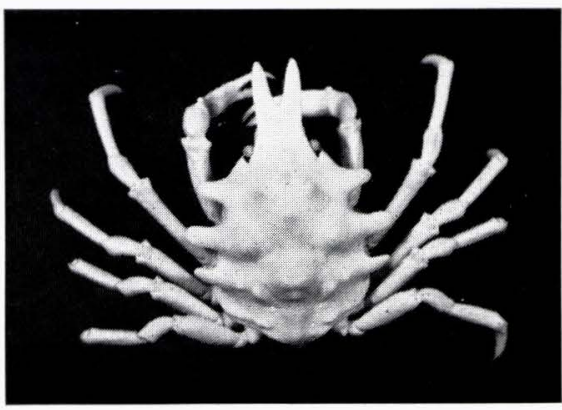

3

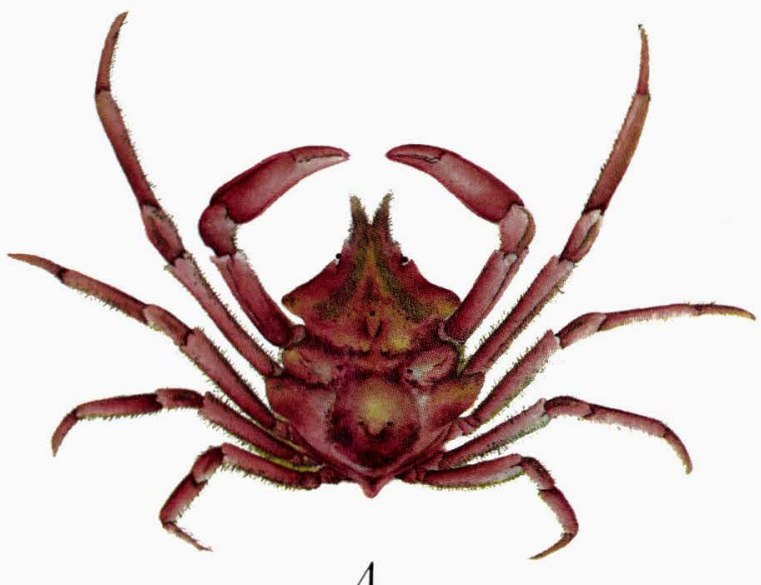

4

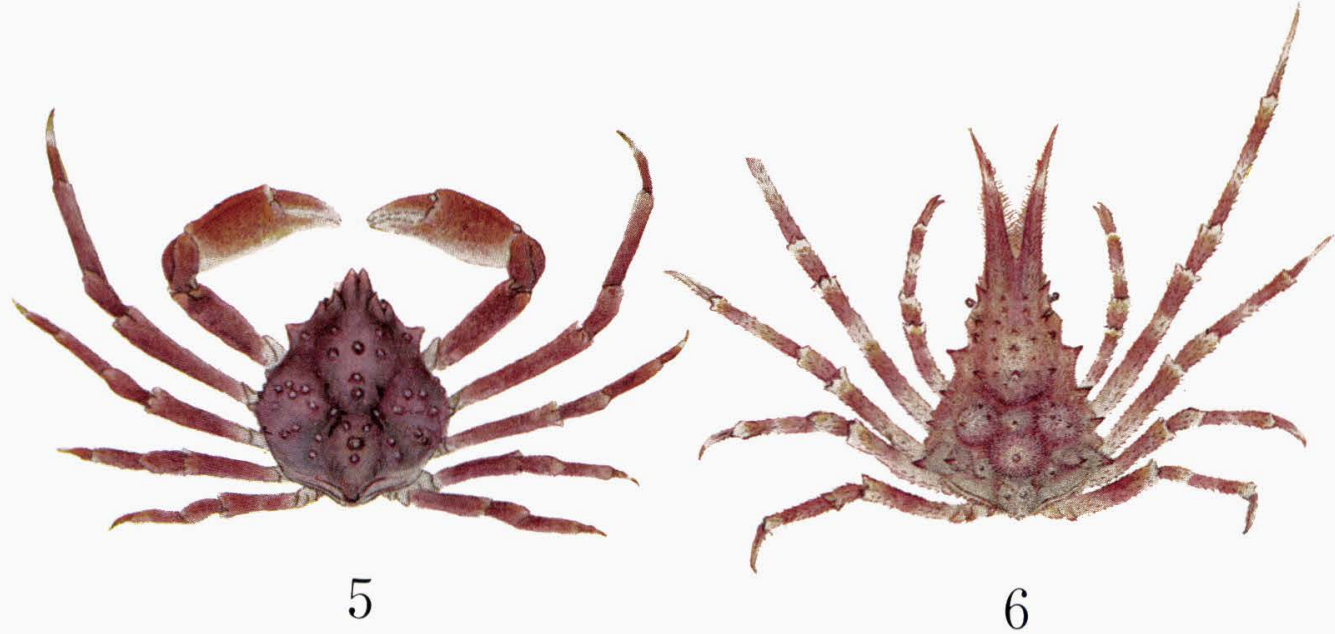

1. Pugettia quadridens de HAAN ヨッハモガ二

2. Pugettia incisa de HaAN ヤワズモガ二

3. Goniopugettia tanakae SAKAI タナカオニモガニ (n.g. et sp., photo by S. TANAKA)

4. Goniopugettia sagamiensis GORDON サガミモガ=

5. Pisoides bidentatus (A.M. EdwARdS) オオトガリガニ (SAKAI, 1956 より)

6. Naxioides mammillata (ORTMANN) エダッノガニ (SAKAI, 1956 より)

For explanation of figures, see page 1. 
Researches on Crustacea, No. 15

Carcinological Society of Japan

Odawara Carcinological Museum

Azabu-Juban 3-11, Minatoku, Tokyo

(Issued-April 30, 1986)

珍奇なる日本産蟹類の属と種について

口絵 1, 図版 I-III, 插図 1

酒井恒

（日本甲殼類学会）

\section{RARE SPECIES AND THEIR GENUS OF CRABS IN JAPAN}

With 1 Frontispies, 3 Plates, 1 Text-figure

By

Tune SAKAI

(Carcinological Society of Japan)

1. Goniopugettia sagamiensis GoRDON について

1904年，西ドイッの DoFLEIN はヴァルディヴィァ深海探検の報告 [Deutchen Tief-see Expedition auf dem Valdivia 1898-1899] の p. 85, Pl. XXVII, figs. 13, 14 に於いて, ッノ ガニの 1 種 Hyastenus brevirostris なる新種をスマトラ島の西南岸から記載している。その属 と種の決定については甲殼類学者の SARS 及び ALCOCK の 2 人の教示に俟って, 額轓と歩脚 の短い点と甲殼の表面の䄉毛を去った後の突起や棘等から判定して新種は既に記載されている Hyastenus pleione, 又は H. hilgendorfi に近い種であることが 2 人の学者によって指摘された。

1915年に伊太利のブルノー, パリシ (B. PARISI) なる学者は日本の相模湾の蟹類についてミ ラノの博物館の資料に基づき I. Decapodi Giapponesi del Museo di Milano を刊行し，その P1. 7, p. 287 に Pugettia brevirostris なる種類の蟹を発表しその図は精細な写真であるので明ら かにこれは DofleIN の p. 85, Pl. XXVII, figs. 13, 14 の種と同名であるので, British Museum の Dr. Isabella GoRDON は 1931 年に刊行した中国の蟹（アモイ，ホンュン，中国，相模湾の 蟹）の p. 556, text-fig. 35 飞 Pugettia sagamiensis なる蟹の甲殼の全図を掲載し Pugettia brevirostris PARISI, nec DOFLEIN の異名同種なるが故に新名を変更している。このゴルドン 博士の名称 Goniopugettia が新名として新しいPugettia の名前と変って1959年の 1 月, 酒井 はこれをGoniopugettia という名前に変えた。その理由は後述の通り, Pugettia 属ではないか らである。な拉 DOFLEIN の1904年の Hyastenus brevirostris (Pl. XXVII, figs. 13, 14) は I. GORDON の p. 557 の text-fig. 36, a に正確な線画で画かれていて Pugettia brevirostris と

して画かれている。 


\section{Pugettia 属}

この属の蟹は，日本の岩礁の浅所にごく普通にみられる蟹で，和名をよつはもがに属という。 甲面には絨毛が密生する。これを取り去ると甲面には隆起が多い。額棘及び胸脚の長節・腕節 前節・指節それぞれの前縁や後縁にも䄉毛が多く生じている。体の大きさはむしろ小型で，大

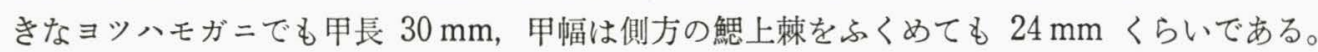
体色は甲殼が一様に褐色または暗緑色で，時には黄褐色を呈するものがある。この属の雄の腹 肢は必ず先端が三葉に分岐している(P1. I, 7・8・9)。

日本産 Pugettia 属は下記の10種におよんでいる。

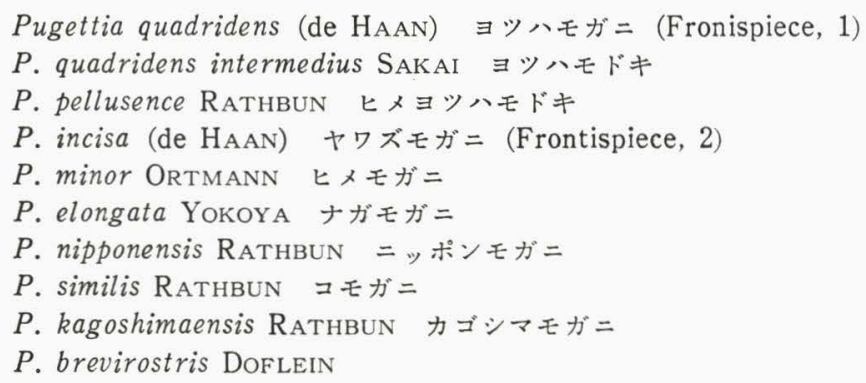

Goniopugettia 属, 酒井 (1957)

この属が Pugettia 属と異なるおるな特徵は；1. 大型の蟹である。通常の大きさでは, 甲長 $54 \mathrm{~mm}$, 甲幅 $45 \mathrm{~mm}$ 以上あり, 甲面には䋐毛が多い; 2. 色彩は深紅色で胸脚も赤い; 3. 額棘 はほぽ平行し, 胸脚の長節・腕節・指節は前縁後縁に䄉毛が密生する。眼上枝は発達し, ここ にも䋐毛が密生している；4. 雄の第一腹肢はまっすぐで先端は三岐していない(Pl. I，6）など があげられる。

Goniopugettia tanakae n.g., n. sp. タナカオニモガニ (Frontispies, 3)

$3 \hat{\circ} \hat{\jmath}, 2$ 우우, Off Enoshima, SAKAI

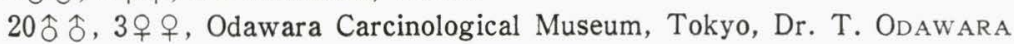

$3 \hat{\delta}\}, 2$ 우우, Off Hayama, Mr. H. IKeda, Mr. T. Watanabe

$3 \hat{ᄉ} \widehat{0}, 2$ 우우, Kii Minabe, coll. by Mr. M. OzAKI

$10 \hat{\delta}$, 5 우우, Tosa Mimase, coll. by K. SAKAI

1ิ̂, Tosa Murotozaki, coll. by Mr. K. Matsuzawa

$2 \hat{\jmath}, 1$ 우, Nagasaki, coll. by Mr. M. Matsuo

種名は三重県鳥羽の熱心な採集家本居博物館長, 田中信一氏の名前を記念するためのもので ある。本属の第 2 番目の種である。

本種は大形で雄の甲殼の長さは $60 \mathrm{~mm}$, 甲幅 $55 \mathrm{~mm}$ にたっする。体全体の色彩は一様に深 紅色である。眼上板はよく発達し, 甲の両側に 3 個の隆起があり, 心域も高く突出する。雄の 腹肢は細く，まっすぐで，先端がPugettia 属のように三葉に分岐することはない。鉗脚や歩脚 の各節は板状で平たい。

2. Parapleisticantha japonica YoKOYA, 1933. ヤマトハリセンボンについて この属の蟹は Pleistacantha MIERS, 1879 (ハリセンボン属)に近い属で横屋氏が 1933 に書い 
た属で japonica 1 種を含み, 横屋氏*が 1933, p. 140 に述べた以外にその記録はない。最近 名古屋の採集家飯柴英次氏がはじめてこの種 の文 1 匹，紀伊半島沿岸から採集したので この属の二度目の採集である。

小形種で額棘は短かく左右広く開き，鈷脚 歩脚共に短小で棘毛もまた短かい，甲面の棘 も短小である，甲域にある 4 個の小棘は小さ くて不顕著，額棘は短かく開度ひらき鈍い。

3. 東京湾の地中海ミドリガニについて

A

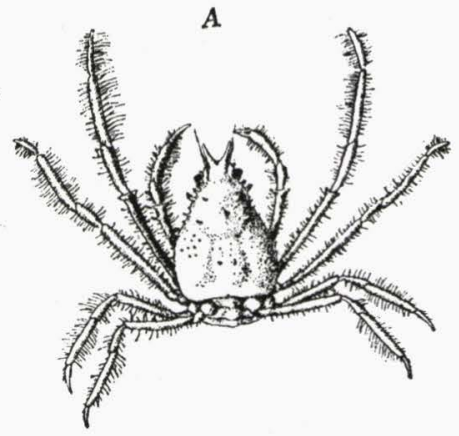

Text-fig. 1. Parapleisticantha japonica Yокоу A A. 背面, B. 口部腹面 (after YoKоYA, 1933)

わたりがに科 (Portunidae) の中で原始的な Carcininae (=Carcinidae) と呼ぶ亜科がある。 その亜科の中に Carcinus (Carcinides) RATHBUN という 1 属があって Carcinus (Carcinides) 属が最基礎をなし Carcinus maenus=Carcinides maenus（Pl. II, 2) がその基礎をなし，ヨー ロッパ南米，ハワイ各地に分布しているが東洋の中国，日本にはその分布を見ない。この属に 地中海の種名のついた Carcinus meditterraneusなる1種があってアメリカでもアジアにも産せ ずただ地中海にのみ産し「地中海ミドリガニ」なる和名をおびている (mediterranean green crab=Carcinus mediterraneus CZERNIAvsky；Pl. II, 1・3)。この珍奇なカニがいかなる方法に よったものか不明であるが, 1959 年の夏以来東京湾から多量に採集されるようになった。1959 年の10月, 葉山の熱心な採集家, 日本甲殼類学会会員の池田等氏がはじめて千葉県浦安の海岸 から地曳網の残物の中からこのカニの抱卵した死雌の標本を採集した。引き続いて 同氏は同地 から雄の死標本 2 個を採集したのである。1960年に筆者が訪欧した際パリにて Dr. J. FoREST から見事な地中海ミドリガニの $1 \hat{\delta}$, Carcinus maenus の $1 \hat{\delta}$, 地中海ミドリガニとヨーロッパ の Carcinus maenus 両種の今の腹肢を露出させた写真をいづれも提供され, 比較することがで きた。又熊本大学の天草臨海実験所の山口隆雄教授はナポリ産の 地中海みどりがにの完全な標 本 3今令, 1を比較のために提供して下さったので東京湾のカニが地中海のかにと同種である ことが判然とした。昭和 59 年の 8 月 21 日, 横浜の磯子海岸に多くの磯の動物が這い上り, 神奈 川新聞社の写真部長江島氏がその写真を撮影してあってそれを提供して下さったので東京湾に 地中海ミドリガニが拡散していることがわかったのである (Pl. III)。その拡散した方法は不明 ではあるが(1)地中海や大西洋の章魚が食料の材料として多量に冷凍して日本の各地の市場に送 られてくるが，その中に地中海ミドリガニの生存した個体が混じていたか，いまひとつは大型 の艦船のバラスト水槽の中に地中海ミドリガニの幼ガニが混入してきて東京湾に移住したかの いづれであろう。いづれにしても東京湾に地中海だけにいる地中海ミドリガニが移住した事実 は珍奇なことである。神奈川新聞の写真部長江島氏と 熊本大学天草臨海実験所の山口隆雄教授 の二人の御助力に深い感謝の意を捧げる次第である。

4. ツノガニの化石について

1977年に東海化石研究会長, 西沢勇氏は, 愛知県の化石という表題で名古屋港浚渫工事の折 *Yokoy a, Y, 1933: J. Coll. Agricult., Tokyo Imp. Univ. Vol. 12, No. 1. 
に得られた多くの化石, 半化石についてとの第一集を刊行して多くの浅海底の 動物が 記載され ている。その Pl. 8, Pl. 9, Pl. 10 には多くのツノガニ類が記載してあり, Pl. 8 (p. 20) にはト ウカイェダッノガニ (Naxioides sp.), エダッノガニ (Naxioides) は成体 4 体と幼体 2 体が画か れているが額棘がいづれも短かする。また 2 本の額棘がいずれも内縁の末端に近く小さい副棘 を有することが本属の特徵である。然るに化石の図ではこれがなく，甲幅もせまいので別属の ように思える。口絵の Fig. 6 を参照されたい。また Pl. 11 (p. 24) にはナゴャクモガニ Platymaja sp.) とあるが，甲幅が大きく Platymaja とは見られない。むしろ口絵の Fig. 5 に示し てある Pisoides bidenlatus であろうと思う。

これらのうち第 8 図版の 7 図 (1-a-c, 2-a-b) の 5 図は成体であり和名はトウカイェダッノガ

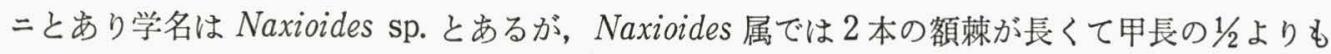
長く夫々の内側に先端に近く小さい副棘がある, 種類としては Naxioides mammillata のほか に N. hystrix, N. taurus, N. hirta 等の別種があるが, 第 8 図版の種類はその何れの種類にも 該当していない。

またその第 9 図版の 6 種類の中， 1 の a b b 2 はツノガニ，3，a-b，4 はヤハズモガニであ ろう。図版11 (page, 34) の種は額棘短小で甲幅が大きいので多分 Pisoides 属(図版 79) と同 じ種であろう。 
Explanation of Plates

I-III 


\section{Explanation of Plate I}

1. Hyastenus brevirostris (ventral view) after DofLEIN (1940)

2. The same (dorsal view)

3. Pugettia brevirostris after GoRDON (1900)

4. Pugettia sagamiensis after GoRDON (1931)

5. Pugettia brevirostris after PARISI (1912)

Both $P$. sagamiensis and $P$. brevirostris are synonymous with Goniopugettia sagamiensis SAKAI, 1959

6. Male 1st pleopod of Goniopugettia sagamiensis

7. Male 1st pleopod of Pugettia quadridens

8. Male 1st pleopod of Pugettia incisa

9. Male 1st pleopod of Pugettia nipponensis 

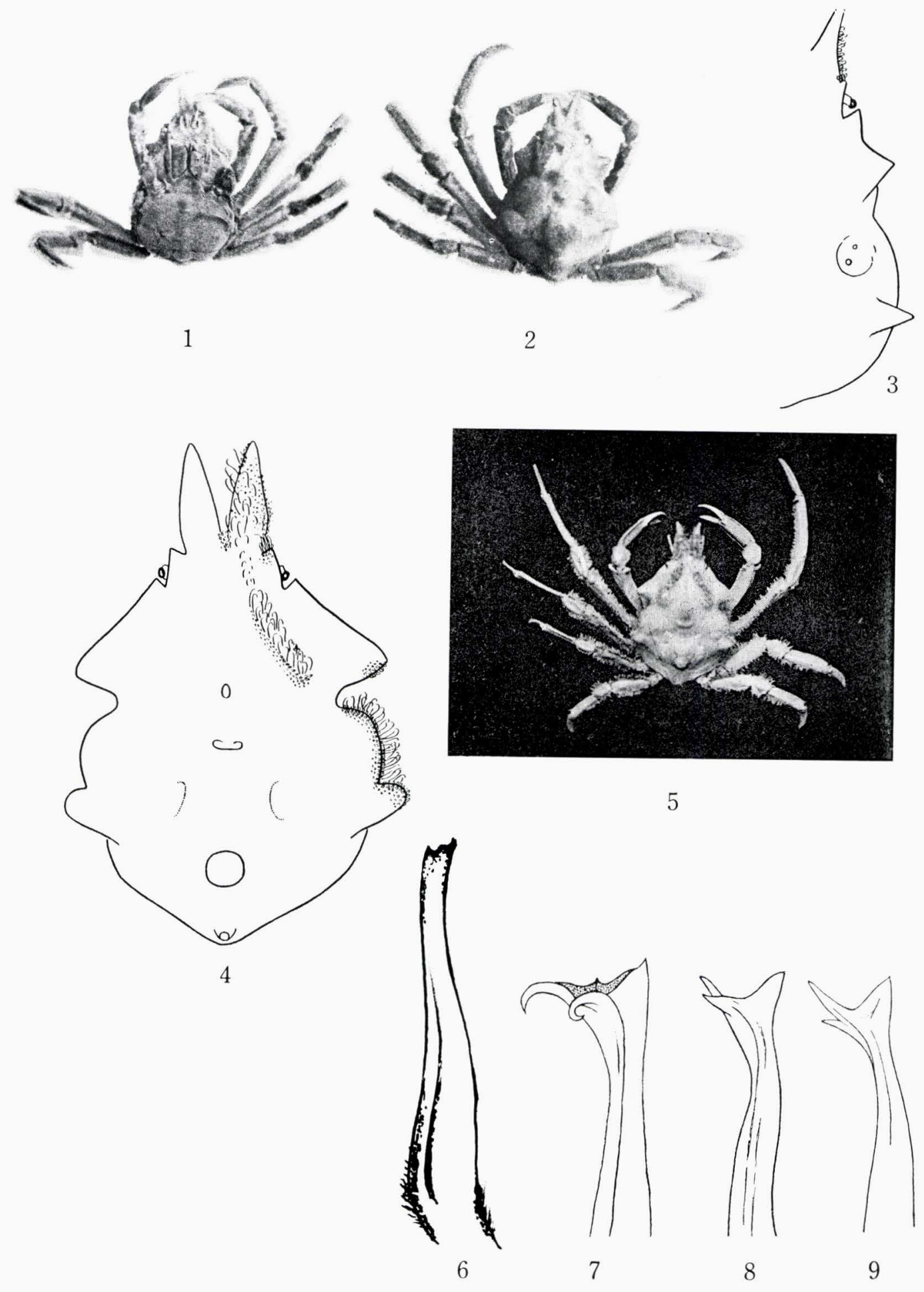


\section{Explanation of Plate II}

Above: Carcinus mediterraneus CZERIAVSKY チチュウカイミドリガニ (仓̂)

(Photo after J. Forest, 1960-Specimen from Barcelona)

Below, left: Male 1st pleopod of Carcinus maenus

(Photo after Dr. J. Forest)

Below, right: Male 1st pleopod of Carcinus mediterraneus CZERIAVSKY

(Photo after Dr. J. Forest) 


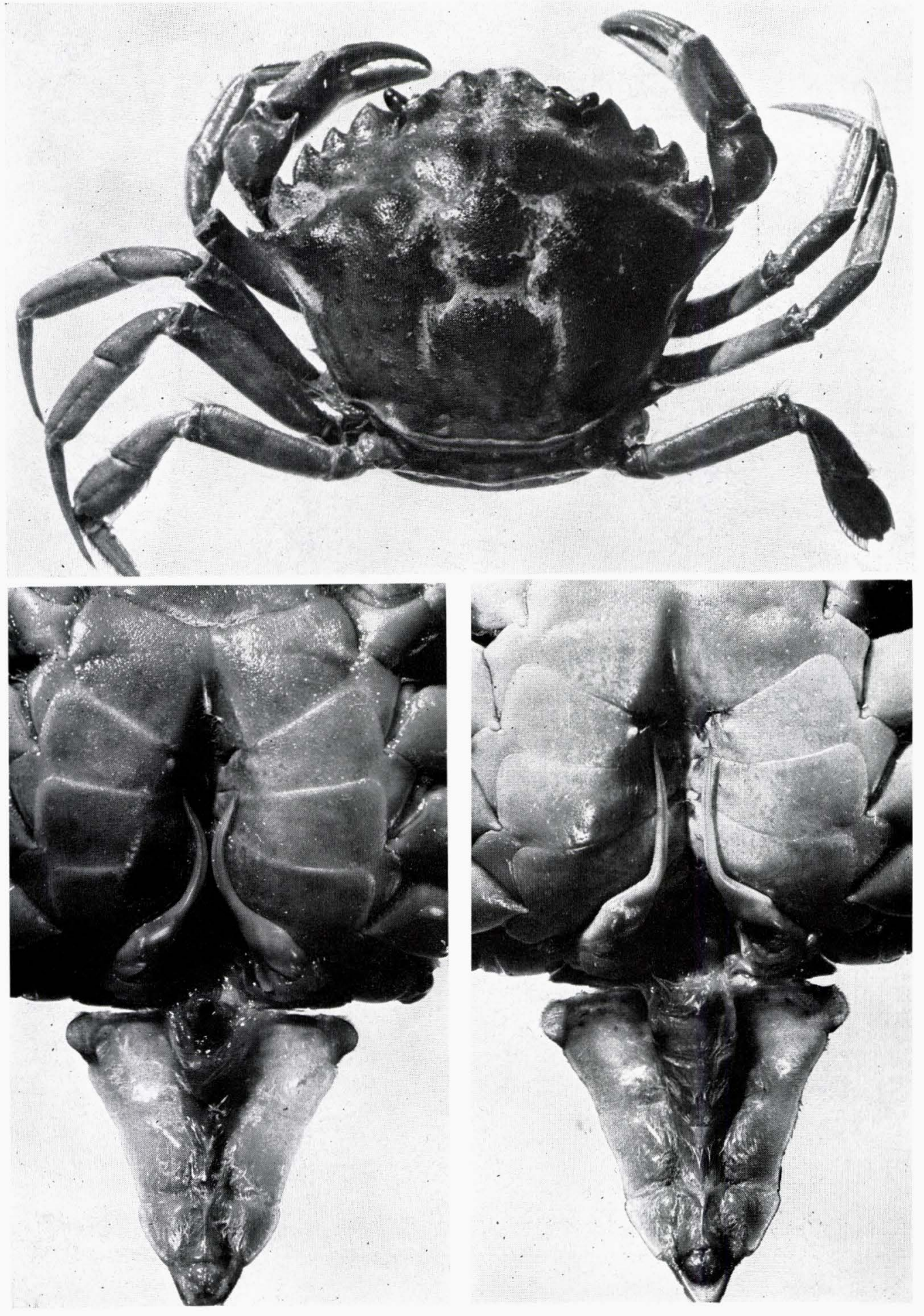




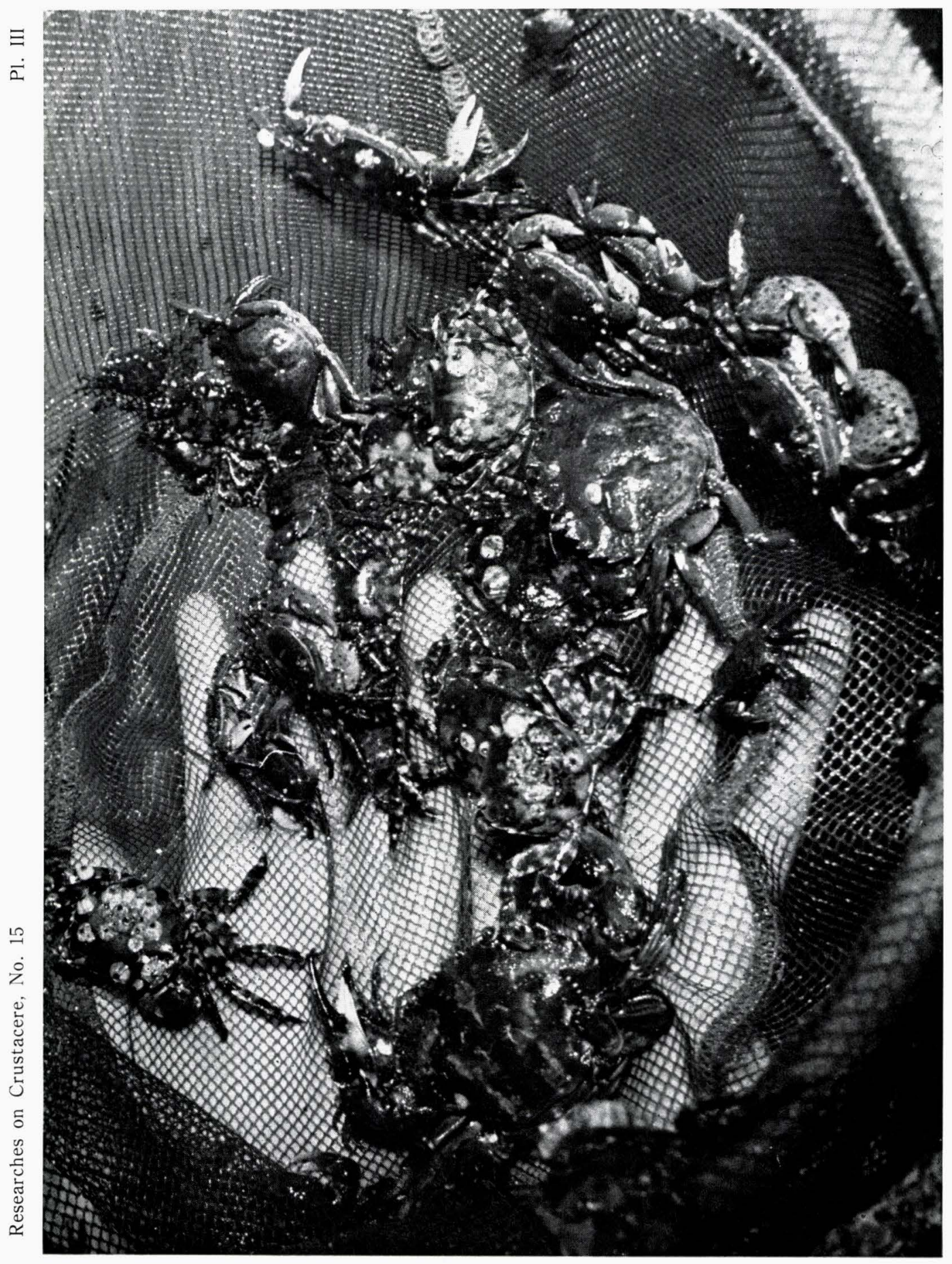

